\title{
НОВІTHІ ЧАСИ
}

УДК 94 (477) : [304.4 : 364.69] «192»

DOI: https://doi.org/10.33782/2708-4116.2021.4.96

Зінаїда Священко

\section{СОЦІАЛЬНА ПОЛІТИКА РАДЯНСЬКОЇ ВЛАДИ ЩОДО ОХОРОНИ МАТЕРИНСТВА ТА ДИТИНСТВА В УСРР 1920-х рp.}

\begin{abstract}
Анотація: У статті досліджується соціальна політика радянської влади у питанні охорони материнства та дитинства 1920-хрр. Проаналізовано процес розвитку соиіального інституту охорони материнства та дитинства в УСРР. З'ясовано, що практично з перших днів радянської влади охорона материнства та дитинства отримує державний статус. Обірунтовано основні тенденції правових та організаційних форм захисту материнства та дитинства досліджуваного періоду, результатом дії яких стало створення ясел, дитячих садочків, молочних кухонь, дитячих і жіночих консультацій. Дошкільні заклади організовували для дітей відповідний режим проживання та харчування, проводили профілактичні огляди та щеплення. Для вирішення питання дитячої безпритульності до середини 1920-хрр. у структурі Наркомату освіти УСРР була утворена мережа дитячих закладів для постійного перебування дітей: дитячі будинки, колонії та містечка. У них був організований навчально-виховний і виробничий процеси.
\end{abstract}

Ключові слова: Украӥнська СРР, державні органи, соціальна політика, материнство, дитинство, дитячі заклади, безпритульність

Дослідження проблеми соціальної політики держави у галузі охорони материнства та дитинства буде завжди актуальним, а в реаліях сьогодення вона набуває особливого значення. Сучасна українська державна система охорони материнства та дитинства суттєво постаріла і потребує комплексного оновлення. На порядку денному компетентних державних органів має стати удосконалення законодавчої бази у питанні охорони материнства та дитинства, стандартизації надання їм допомоги та послуг, налагодження механізмів фінансування. Сім'ї часто не приділяють належної уваги вихованню й утриманню дітей, що тягне за собою зростання девіантної поведінки серед неповнолітніх. Наслідками кризового становища інституту охорони материнства та дитинства також стала складна демографічна ситуація в Україні.

Як вихід із ситуації, яка склалася, на законодавчому рівні висуваються пропозиції повернутися до таких, уже випробуваних у вітчизняній історії, заходів, як нагороди для багатодітних матерів, податок на бездітність, створення особливих рад для захисту інтересів

\footnotetext{
* Священко Зінаїда Василівна - доктор історичних наук, професор кафедри всесвітньої історії та методик навчання Уманського державного педагогічного університету імені Павла Тичини (Умань, Черкаська область, Україна); ORCID: http://orcid.org/0000-0001-5845-3115; e-mail: szv09@meta.ua
} 
жінок, недержавних фондів охорони материнства та дитинства тощо. Звернення до досвіду вирішення проблем створення та функціонування інституту охорони материнства та дитинства пояснюється не тільки дієвістю означених вище заходів, але і прагненням сучасних органів влади виробити нові підходи до цих проблем в умовах реформування суспільства.

Вивчення історичного досвіду розвитку соціального інституту охорони материнства та дитинства у 1920-х рр. набуває сьогодні особливої актуальності, оскільки може послужити основою для пошуку нових шляхів вирішення соціально-економічних проблем у цій галузі. 3 іншого боку, у досліджуваному періоді було сформовано особливості цього інституту, знання яких збагатить досвід сучасних вітчизняних владних структур, що виробляють стратегію його розвитку на сучасному етапі. Усе це сприятиме наданню комплексного характеру заходам, що проводяться сьогодні з оновлення сучасного інституту охорони материнства та дитинства.

Наукова розробка означеної проблеми немає комплексного вираження у вітчизняній і зарубіжній історіографії, попри існування значної кількості праць радянської доби, позначених ідеологічною заангажованістю. Серед сучасних вітчизняних науковців дослідженням окремих питань захисту материнства та дитинства займалися О. Артюшенко ${ }^{1}$, Т. Денисенко ${ }^{2}$, О. Анатольєва ${ }^{3}$, А. Зінченко ${ }^{4}$, М. Мельничук ${ }^{5}$, О. Бахтіяров ${ }^{6}$.

3 огляду на актуальність окресленої нами теми, метою даної статті є аналіз процесу розвитку соціального інституту охорони материнства та дитинства у 1920-х рр., з'ясування соціально-історичної суті та виокремлення особливостей цього процесу, його історичного значення.

Період 1920-х рр. в Україні характеризується багатьма складними, суперечливими та трагічними подіями. Однак і сьогодні ми маємо потребу детально з'ясувати, як у ті тяжкі для України роки державна влада втілювала в життя політику охорони материнства та дитинства, які результати з цього отримала. У радянський період української історії питання охорони материнства та дитинства були на порядку денному органів державної влади, оскільки радянська держава і суспільство позиціонувалися як нові гуманістичні системи, що передбачали відсутність приватної власності та експлуатації, набуття свободи людиною праці.

\footnotetext{
${ }^{1}$ Артюшенко О. До питання про охорону материнства та дитинства в УСРР у 1928-1933 рр. Гуржіївські історичні читання: Збірник наукових праць. 2009. Вип. 3. С. 278-282.

${ }^{2}$ Денисенко T.M. Становлення та розвиток системи соціального захисту населення в Україні. Ефективність державного управління. 2012. Вип. 33. С. 96-103.

${ }^{3}$ Анатольєва О. Державно-правовий захист неповнолітніх в УСРР (20-ті рр. ХХ ст.). Право України. 2009. № 4. C. $170-174$.

${ }_{4}^{4}$ Зінченко А.Г. Дитяча безпритульність в Радянській Україні в 20-х - першій половині 30-х рр. XX століття: Автореф. дис... к. іст. н.: 07.00.01. Одеса, 2002. 20 с.

${ }^{5}$ Мельничук М.О. Організаційно-правове забезпечення охорони материнства і дитинства в УСРР на початку 1920-х рр. Громадянське суспільство в Україні: проблеми забезпечення правотворчої діяльності: міжнародна науково-практична конференція (м. Харків, 3-4 квітня 2015 р.). Харків: Східноукраїнська наукова юридична організація, 2015.

${ }^{6}$ Бухтіяров О.А. Доктринальна характеристика генезису інституту материнства і дитинства в Україні: історичний аспект. Науковий вісник Ужгородського національного університету. Серія: Право. 2018. Вип. 53. T. 2. C. 24-27.
} 
У таких інституціях, що формувалися на принципах соціалізму, особливого значення намагалися надавати людським ресурсам, які, у свою чергу, впливали на становлення нових типів суспільних і державних відносин. Відбувалася повна зміна моделі побудови сім'ї, а також загального ставлення до жінок і дітей. Це було пов’язано з тим, що соціальна політика радянської влади у 1920-х рр. була спрямована на піднесення ролі робітничого класу як соціальної основи «диктатури пролетаріату». Держава прагнула зміцнити єдину офіційну ідеологію - комуністичну - в усіх сферах суспільного життя. Це, у свою чергу, проявлялося у сімейних відносинах. Зокрема, комуністична ідеологія ввела у національну правову систему інститут емансипації, а також об'єднала правовий статус жінки та дружини․

Практично з перших днів радянської влади охорона материнства та дитинства отримує державний статус. У грудні 1917 р. колегія Народного комісаріату державного піклування, очолювана О. Коллонтай, прийняла рішення про створення Відділу охорони материнства та дитинства, який розпочав функціонувати 31 січня 1918 р. на чолі з В. Лебедєвою. Декретом Наркомату державного піклування від 30 січня 1918 р., усі установи, що займалися обслуговуванням матері і дитини, було передано у відання цього відділу ${ }^{8}$ Оскільки боротьба з високою смертністю була висунута на перший план, відділ розгорнув широку роботу з організації будинків немовляти, жіночих будинків і дитячих лікарень.

Зі встановленням в Україні більшовицької влади 16 січня 1919 р. при Тимчасовому робітничо-селянському уряді України уже 2 лютого 1919 р. на базі відділу охорони здоров'я було створено Народний комісаріат охорони здоров'я. Його першочерговими завданнями визначалося здійснення підготовки та розроблення законодавчих норм у галузі медикосанітарної справи, організації та керівництва центральними медико-санітарними установами і місцевими органами охорони здоров'я, забезпечення фінансового контролю та допомоги всім медичним установам. Положенням РНК УСРР була визначена структура Наркомату. Він формувався з колегії, управління справами та відділів (військово-санітарного, санітарноепідеміологічного, лікувальної медицини, шкільної санітарії, постачання, страхової медицини, фінансового). Місцевими органами Наркомату стали відділи охорони здоров'я при губернських, повітових і волосних виконкомах. Вони повинні були здійснювати керівництво медико-санітарною справою в межах своїх адміністративно-територіальних одиниць. До їх структури входили також і відділи охорони материнства та дитинства.

Восени 1919 р. у зв'язку з наступом денікінських військ Наркомат охорони здоров'я УСРР, як і всі інші республіканські наркомати, було ліквідовано. Та вже 19 січня 1920 р. при Всеукраїнському революційному комітеті було засновано Комісію охорони здоров'я при Санітарному управлінні Південного фронту. 28 січня 1920 р. Всеукраїнським ревкомом було прийнято постанову про створення Всеукраїнської комісії охорони народного здоров'я, а 20 лютого відновлено діяльність Народного комісаріату охорони здоров'я УСРР ${ }^{9}$. Серед його пріоритетних завдань визначалося забезпечення охорони материнства і дитинства.

\footnotetext{
${ }^{7}$ Михайленко О. Трансформація аксіологічних настанов інституту сім'ї як чинник визначення напрямів державної сімейної політики. Державне управління та місцеве самоврядування. 2015. Вип. 2 (25). С. 182.

${ }^{8}$ Авдеев А. Младенческая смертность и история охраны материнства и детства в России и СССР. Историческал демография: сборник статей. Москва, 2008. С. 29.

${ }^{9}$ Ціборовський О.М. Народний комісаріат охорони здоров'я УРСР. Енииклопедія Сучасної Украӥни: електронна версія [веб-сайт] / гол. редкол.: І.М. Дзюба, А.І. Жуковський, М.Г. Железняк та ін. Київ: Інститут енциклопедичних досліджень НАН України, 2006. URL: http://esu.com.ua/search_articles.php?id=71183
} 
3 самого початку свого функціонування система зосередила зусилля на розвиткові установ закритого типу, таких як будинки дитини, будинки матері та дитини тощо. Фактично створювалася система спеціалізованих лікарень. Значну роль в організації системи медичної та профілактичної допомоги жінкам і дітям відіграли спочатку всеросійські, а потім всесоюзні наради з охорони материнства та дитинства, які скликалися у 1920, 1923, 1925 і 1929 рр. Ці наради мали велике значення у виборі стратегії розвитку системи, вирішенні організаційних питань, розв'язанні завдань підготовки кадрів.

У грудні 1920 р. на Першій нараді з охорони материнства і дитинства було прийнято рішення про пріоритетний розвиток установ відкритого типу, таких, як ясла, консультації, молочні кухні тощо, що можна було б вважати тимчасовою перемогою профілактичновиховного або профілактично-освітнього напряму. Після 1920 р. консультації, що обслуговували дітей до одного року, перетворили у школи матерів. Тоді ж виникають і консультації для вагітних, які спочатку обслуговували лише вагітних, а пізніше - і всіх жінок. Спочатку діяльність дитячих і жіночих консультацій мала суто профілактичний характер, але поступово вони почали набувати і лікувальних функцій. Ставало зрозумілим, що взяття консультаціями на себе лікувальних функцій, швидко підірве їх профілактичнопросвітницьку діяльність. Тому упродовж 1920-х рр. велися активні дискусії про перспективи охорони материнства і дитинства в СРСР, зокрема, висувалися пропозиції про посилення спеціалізації установ шляхом створення мережі окремих консультацій: для вагітних, для гінекологічних хворих, служби планування сім'ї, дитячі консультації ${ }^{10}$.

Автори таких пропозицій, як правило, лікарі-практики, на власному досвіді доводили неможливість ефективної роботи при безпосередньому поєднанні лікувальної та профілактичної діяльності. Однак їх позиції залишилися невизнаними, і з 1930 р. на жіночі консультації було покладено завдання лікування гінекологічних хворих. 3 того часу вирішення цього завдання стало безумовною домінантою їх діяльності. У результаті на початку 1930-х рр. складалася триступенева система, яка існує до сьогоднішнього дня та включає в себе: жіночу консультацію, яка здійснює лікування гінекологічних хворих, діагностику вагітних; пологові будинки, які з 1927 р. були включені до системи материнства і дитинства; дитячі поліклініки, лікарі яких спостерігають і лікують дітей від моменту їх прибуття з пологового будинку і до 15-річного віку.

Важливим елементом системи охорони материнства і дитинства стали установи «несімейного виховання» - дитячі ясла, куди жінки могли віддати дитину віком від 2-3 місяців, та дитячі садочки, призначені для дітей від трьох до семи років. Ці установи відігравали позитивну роль в оздоровленні дітей і зниженні дитячої смертності, оскільки і в містах, і в сільській місцевості санітарні умови утримання в них дітей були в середньому набагато кращими, ніж ті, які існували в сімейному помешканні. У дошкільних закладах на дітей поширювався відповідний режим життя і харчування. У них регулярно проводилися профілактичні огляди та щеплення. Однак головним завданням дитячих ясел у ті часи було забезпечення своєчасного повернення жінки на робоче місце.

У цей же час було прийнято низку нормативно-правових актів, які змінювали шлюбносімейні відносини, а також їх соціальне сприйняття. У цьому питанні значну роль відіграли

${ }^{10}$ Авдеев А. Младенческая смертность... С. 32. 
такі нормативно-правові акти, як декрети «Про розірвання шлюбу», «Про громадянський шлюб, дітей та ведення актів громадянського стану», Цивільний кодекс тощо ${ }^{11}$. Означені правові акти закріпили численні норми, що регулювали питання укладення шлюбів, відносини, що виникали зі зміною сімейного стану, а також окремі аспекти виховання дітей.

Створення основ нового законодавства і нової системи державних органів з охорони материнства та дитинства відбувалося в руслі змін, що здійснювалися радянською державою. Ці процеси були пов'язані, перш за все, зі становленням сімейно-шлюбного та трудового законодавства, формуванням організаційних і правових умов для встановлення різних форм соціального захисту дитинства. У перші роки радянської влади, в період економічної розрухи та соціальної нестабільності, виживання дітей як загальносоюзна проблема трансформувалася у політику радянської держави. Діяльність органів з охорони материнства та дитинства була організована на загальнодержавних засадах.

Соціально-економічні та політичні перетворення у післяреволюційний період були спрямовані, у тому числі, і на зміну ролі жінки в соціалістичному суспільстві, яка наділялася тепер рівними правами 3 чоловіком, ставала повноправною учасницею суспільного виробництва. Важка праця внаслідок недотримання санітарно-технічних норм охорони праці на виробництві та залучення жінок до нічних робіт, проблеми із забезпеченням належного харчування, недоступність медичної допомоги для переважної більшості населення, особливо у сільській місцевості, недотримання умов соціального страхування вагітних і матерів спричинило масові захворювання серед жіночого населення, значну недоношеність дітей, високий відсоток материнської та дитячої смертності ${ }^{12}$.

Варто підкреслити, що з самого початку приходу до влади більшовиків, ставлення до охорони материнства і дитинства набуває більше політизованого відтінку, оскільки мова йшла про здоров'я «жінки-робітниці» та створення можливостей поєднання жінкою виробничої праці з материнством ${ }^{13}$.

На початку 1920-х рр. уперше в історії на практиці формується нова модель статусу жінки: дружини, матері, трудівниці. Радянське трудове законодавство було більш досконалим порівняно з дореволюційним: залучення жінки до громадської діяльності супроводжувалося створенням і розвитком законодавчої бази, що регулювали працю жінок шляхом створення сприятливих умов для поєднання виробничої діяльності 3 материнством, наданням спеціальних пільг вагітним жінкам і матерям, що годували груддю, призначення допомоги при вагітності та пологах.

У лютому 1920 р. при місцевих ревкомах, в системі органів Наркомату соціального забезпечення УСРР було створено секції охорони материнства та дитинства. Завданнями їх діяльності ставали вирішення питань заснування нових і розширення існуючих закладів 3 охорони материнства та дитинства, забезпечення матерів предметами вжитку та догляду за

\footnotetext{
${ }^{11}$ Бухтілров О.А. Доктринальна характеристика генезису інституту материнства і дитинства в Україні... С. 26.

${ }^{12}$ Ткач Л.И. История охраны материнства в дооктябрьский период и развитие ее на Украине за годы Советской власти (1844-1967): Автореф. дис... канд. мед. н. Харьков, 1969. С. 7.

${ }^{13}$ Хорош И.Д. Первые годы развития здравоохранения на Украине (1918-1920). Киев: Госмедиздат УССР, 1963. C. 167.
} 
дітьми, просвітницька діяльність серед вагітних жінок і породіль, нагляд за дотриманням вагітними, породіллями і матерями правил гігієни та догляду за немовлятами ${ }^{14}$.

30 квітня 1920 p. РНК УСРР прийняв постанову про передачу справи охорони материнства та дитинства від Наркомату соціального забезпечення до Наркомату охорони здоров'я з виокремленням у структурі місцевих органів управління профільних підвідділів. Перед ними було поставлено завдання пошуку ефективних форм і методів організації охорони здоров'я жінок і дітей. Вони відкривали дитячі медичні установи, організовували підготовку патронажних сестер, закріплювали лікарів за школами, дитячими садочками та майданчиками.

До компетенції органів охорони здоров'я входило оформлення документів на отримання грошової допомоги матерям, які годують груддю, вагітним, породіллям, а ії видачею займалися органи Наркомату соціального забезпечення. У такий спосіб намагалися досягнути єдності всіх заходів, що стосувалися охорони здоров'я матері та дитини, починаючи від допомоги породіллям і завершуючи створенням мережі консультацій і дитячих ясел, в яких мати та їі новонароджена дитина отримували лікувальну та профілактичну допомогу. У республіці оформлювалася система профілактичних установ і суспільно-державних заходів 3 охорони материнства та дитинства. Відкривалися консультації для дітей і вагітних, постійні ясла, а у сільських місцевостях - районні консультації та польові ясла. У консультаціях для дітей облаштовувалися молочні кухні ${ }^{15}$.

Нормативні акти Всеукрревкому, пізніше Раднаркому УСРР на початку 1920-х рр. засвідчують певну міру забезпечення інтересів вагітних жінок, матерів і дітей. Першочерговими стояли завдання налагодження дитячого харчування. Досить ретельно було розроблено положення про дитяче громадське харчування. В його основу було покладено створення їдалень при навчальних і виховних закладах, дитячих садках, школах та інтернатах. Крім шкільних їдалень, під загальним керівництвом Наркомату продовольства УСРР та за участі секцій дитячого харчування Наркомату охорони здоров'я формувалася система дитячих громадських їдалень загального користування. У свою чергу Наркомат охорони здоров'я та його місцеві органи здійснювали медико-санітарний нагляд за дитячими їдальнями, школами й іншими дитячими закладами, в яких організовувалось дитяче харчування ${ }^{16}$.

Охорона здоров'я дітей і підлітків здійснювалася в організованих колективах, перевага надавалася піонерам і працюючим підліткам, запроваджувалися посади піонерських лікарів. На державному рівні вивчалося санітарне становище шкіл і дитячих закладів, їх режим, організація занять фізичною культурою, а також фізичний розвиток дітей. 31921 p. на території УСРР для оздоровлення дітей у літній період почали організовувати піонерські табори, будинки відпочинку для піонерів і працюючої молоді, дитячі колонії ${ }^{17}$

За звітами станом на січень 1921 р. більшовикам вдалося заснувати 264 заклади охорони материнства та дитинства, з яких 43 у великих губернських містах, а решта - у повітових

\footnotetext{
${ }^{14}$ Работа в сфере Охматдета. Звезда. 1921. 9 июля. С. 1.

${ }^{15}$ Охорона здоров'я в УРСР: Основні закони та урядничі розпорядження / За ред. М. Спаського. Київ-Харків: Медвидав, 1932. С. 13.

${ }^{16}$ Баткіс Г.А. Перші кроки будівництва радянської охорони здоров'я на Україні (1918-1922). Київ: Держвидав УРСР, 1964. С. 6.

${ }^{17}$ Федотова О. Охорона материнства і дитинства на Україні. Харків: Наукова думка, 1930. С. 12.
} 
центрах і невеликих містечках й лише окремі - у селах. В республіці нараховувалося також 58 консультацій, 13 молочних пунктів, 30 постійних ясел, 12 будинків матері і дитини, 6 будинків немовлят, 7 розподільників тощо. 3 усіх спеціалізованих закладів - майже половина були закритого типу ${ }^{18}$.

Станом на жовтень 1923 р. в УСРР нараховувалося 28 дитячих санаторіїв, з них 13 діяли на постійній основі, а 15 - посезонно. Санаторні ліжка по губерніям розподілялися наступним чином: у Київській - 640, Харківській - 472, Подільській - 200, Чернігівській 100, Волинській - 156, Донецькій - 65, Одеській - 200, Полтавській - 210 ліжок. Наприклад, протягом літнього сезону 1923 р. санаторії змогли обслужити 2694 хворих дітей. 3 них 53\% були діти колишніх безпритульних, інші - діти робітників. Також було проведено кампанії по зміцненню дитячих закладів ${ }^{19}$.

Уже в перші роки радянської влади розпочалося створення системи охорони дитинства, яка включала в себе вироблення нормативно-правової бази з охорони дитинства, державні та громадські установи боротьби з дитячою безпритульністю, мережу дитячих будинків для безпритульних дітей і різноманітні види соціальної допомоги для нужденних дітей. У період 1920-1923 рр. ВУКВК і РНК УСРР було видано низку нормативно-правових актів, якими регламентувалася діяльність органів та установ народної освіти у питаннях захисту дитинства та боротьби з дитячою безпритульністю: «Про неповнолітніх» (червень 1920 р.), «Про охорону дитинства» (травень 1921 р.), «Про заходи боротьби з дитячою безпритульністю» (червень 1921 р.), «Про наділення землею дитячі заклади соціального виховання» (січень 1922 р.), «Про забезпечення дітей-сиріт» (квітень 1923 р.) ${ }^{20}$. Для впорядкування процесу організації мережі дитячих закладів для безпритульних дітей Наркомат освіти УСРР видав низку положень: «Про дитячу трудову колонію», «Про трудову комуну для підлітків», «Про прийомні пункти», «Про створення відкритих дитячих будинків» ${ }^{21}$.

Причини дитячої безпритульності з початку 1920-х рр. і до середини 1930-хрр. змінювалися. У перші роки радянської влади партійно-державні органи вважали безпритульність породженням недолугої соціальної політики царизму та неузгодженість роботи відповідних установ. Така оцінка причин безпритульності зумовлювала і підхід до цього явища - ліквідацію безпритульності, а не причин, що їх породжували ${ }^{22}$.

Фактично ж, на початку 1920-х років це явище було породженням негативних наслідків війн і революцій, економічної розрухи наступного періоду, голоду, що охопив більшу частину країни. Більше половини безпритульних дітей-бродяг становили неповнолітні, що залишилися без батьків. Варто підкреслити, що проблема дитячої безпритульності виникає найбільш гостро, коли відбувається соціальна патологія життя суспільства, його структурна деформація, соціальні потрясіння та відображає до певної міри психологію людей перехідного періоду.

\footnotetext{
${ }^{18}$ Ibid. C. 11.

${ }^{19}$ Мельничук М.О. Організаційно-правове забезпечення охорони материнства і дитинства в УСРР... С. 15.

${ }^{20}$ Збірник постанов і розпоряджень робітничо-селянського уряду України. 1920. №6. С. 146; Збірник постанов і розпоряджень робітничо-селянського уряду України. 1920. №10. С.187; Збірник постанов і розпоряджень робітничо-селянського уряду України. 1921. № 11. С. 293.

${ }^{21}$ Центральний державний архів вищих органів влади і управління України (далі - ЦДАВО України). Ф. 166. Оп. 2. Спр. 1690. Арк. 125; Оп. 1. Спр. 248. Арк. 215, 63.

22 Зінченко А.Г. Дитяча безпритульність в Радянській Україні... С. 9.
} 
Остаточне усунення дитячої безпритульності передбачало корекцію процесу соціалізації дітей, які втратили родину - основну його ланку, і потребували соціальної реабілітації у суспільстві. До середині 1920-х рр. в структурі Наркомату освіти УСРР була утворена мережа дитячих закладів для постійного перебування дітей: дитячі будинки, колонії та містечка. В них був організований навчально-виховний процес і створена мережа виробничих майстерень і сільськогосподарських комун (для набуття дітьми соціальних і професійних навичок). На соціалізацію дітей суттевий вплив мали зміст навчання та виховання, формування якого монополізувала більшовицька держава ${ }^{23}$.

Друга половина 1920 -х років і середини $1930-x$ років характеризується відновленням безпритульності. У середині 1920-х рр. відбулися «якісні» зміни у середовищі безпритульних. Більша половина 3 них мали батьків. Тому органи боротьби 3 безпритульністю прийшли до розуміння необхідності боротьби вже не 3 самою безпритульністю, а з причинами іï виникнення, хоча політичні причини владою ігнорувалися, хоча це їх не знімало з порядку денного. Органи радянської влади як в центрі, так і на місцях вдавалися до здійснення профілактичних заходів попередження безпритульності. У результаті вулична безпритульність стала зникати та втрачати ознаки масового негативного явища.

Тоді ж важливим напрямом правової охорони дитинства у боротьбі з безпритульністю стала розробка та прийняття нових законів, що регулювали положення і влаштування бездоглядних дітей, створення спеціальних уповноважених органів, державних $\mathrm{i}$ громадських організацій 3 ліквідації даного явища. Серед перших декретів радянської влади, головною метою яких став соціально-правовий захист дитинства, був декрет РНК РСФРР про створення комісій у справах неповнолітніх, прийнятий 14 січня 1918 р. Цим декретом скасовувалися суди та тюремне ув'язнення для дітей, які ще не досягли 17літнього віку. Чинність перших декретів поширювалася і на Україну після встановлення на іiї території радянської влади.

Протягом 1920-х рр. до законодавства України були внесені суттєві доповнення. Так, відповідно до Земельного кодексу 1922 р. за неповнолітніми визнавалось право на землекористування, Цивільний кодекс 1923 p. встановлював межі дієздатності неповнолітніх, були внесені також доповнення до статті щодо відповідальності батьків та опікунів за шкоду, яку вони нанесли дітям, а також відновлення права дитини на спадок батьків. Кримінальний кодекс передбачав міри покарання за злочини, які здійснювалися по відношенню до дітей (за сексуальне насилля над дітьми, підміна та крадіжка дітей тощо), а в 1924 р. була введена кримінальна відповідальність за несплату аліментів і залишення дітей в умовах, які загрожують іх життю. За Кримінальним кодексом у редакції 1926 p. передбачалась відповідальність батьків та опікунів за втягнення дітей до жебрацтва ${ }^{24}$.

Отже, упродовж 1920-х рр. органами радянської влади було реалізовано цілий комплекс організаційно-правових заходів, спрямованих на формування системи охорони материнства та дитинства в УСРР. Правова охорона материнства і дитинства здійснювалася шляхом прийняття системи заходів державного регулювання, спрямованих на заохочення

\footnotetext{
${ }^{23}$ Паращевина О.С. Роль системи народної освіти у подоланні дитячої безпритульності в 20-х - першій половині 30-х рр. ХХ століття: Автореф. дис... канд. іст. наук: 07.00.01. Дніпропетровськ, 2005. С. 10.

${ }^{24}$ Зінченко А.Г. Дитяча безпритульність в Радянській Україні... С. 9.
} 
материнства, охорону інтересів матері і дитини, створення найбільш сприятливих умов, що забезпечують повноцінний фізичний і духовний розвиток дитини. Трудове законодавство еволюціонувало у бік підвищення ефективності захисту прав працюючих неповнолітніх, що виразилося у збільшенні гарантій як для міських, так і для сільських дітей.

Zinaida Svyashchenko

\section{Social Policy of the Soviet Government on Protection Motherhood and Childhood in the Ukrainian SSR in the 1920s}

Abstract: The article examines the social policy of the Soviet government on the protection of motherhood and childhood in the 1920s. The process of development of the social institution of motherhood and childhood protection in the Ukrainian SSR is analyzed. It was found out that almost from the first days of Soviet power, the protection of motherhood and childhood received state status. The main trends of legal and organizational forms of protection of motherhood and childhood of the studied period are substantiated, the result of which was the creation of nurseries, kindergartens, dairies, children's and women's consultations. Preschool institutions organized an appropriate lifestyle and nutrition for children, conducted preventive examinations and vaccinations. To address the issue of child homelessness by the mid-1920's in the structure of the People's Commissariat of Education of the Ukrainian SSR was formed a network of children's institutions for the permanent stay of children: orphanages, colonies and towns. The educational and production processes were organized there.

It is established that the legal protection of motherhood and childhood was carried out by adopting a system of state regulations aimed at promoting motherhood, protecting the interests of mother and child, creating the most favorable conditions for full physical and spiritual development of the child. It is proved that during the 1920s the Soviet authorities implemented a set of organizational and legal measures aimed at forming a system of maternity and childhood protection in the Ukrainian SSR.

Keywords: Ukrainian SSR, state bodies, social policy, motherhood, childhood, children's institutions, homelessness 